\title{
A study on the effect of internet on competitiveness and customer loyalty in insurance industry based on Porter competitive forces
}

\author{
Samira Ghazavi* and Mahmood Reza Cheraghali
}

Department of Management and Accounting, Ali abad katoul Branch ,Islamic Azad University, Ali abad katoul, Iran

\begin{tabular}{l}
\hline C H R O N I C L E \\
\hline Article history: \\
Received January 18, 2013 \\
Received in revised format \\
8 June 2013 \\
Accepted 10 June 2013 \\
Available online \\
June 152013 \\
\hline Keywords: \\
Insurance industry \\
Internet \\
Competition
\end{tabular}

\begin{abstract}
A B S T R A C T
This paper presents an empirical investigation to study the effect of internet in insurance industry in Iran. The proposed study designs a questionnaire, distributes it among some experts and analyzes them based on some statistical test. The survey is conducted within insurance firms located in one of provinces of Iran. The results of the study confirm that internet influences competition among providers, bargaining power of customers as well as suppliers, significantly. In addition, internet has meaningful impacts on starting a business, the threat of substitutes, customer satisfaction, perceived image as well as perceived quality. The results of this survey emphasizes on the relative importance of internet for building a better competitive insurance industry.
\end{abstract}

\section{Introduction}

During the past two decades, internet has played essential role on human life. People are now able to connect with other people around world and do business or share their thoughts, substantially (Kim et al., 1998). Web based business models have created tremendous change on many industries including insurance firms (Assael, 1987; Caruana et al., 2000; Porter, 2001). According to Cassiman and Sieber (2002), the internet influences conventional competitive strategies in at least three various ways: (1) the bigger efficiency built by lower transaction expenditures and new organization forms reduce the firms' cost structure, the reduction of consumer's search expenses and new chances for product differentiation and finally electronic markets influences pricing and permit new pricing methods. Feizollahi et al. (2013) provided a conceptual model for selecting and evaluating online marketing in Iran. These findings provide a consistent, targeted and holistic framework for the development of the Internet market in the country.

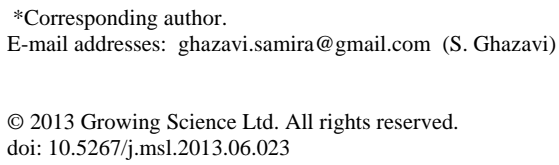


Sehhat (2012) investigated the effect of five factors namely awareness from the site, site attractiveness, promotional effectiveness, effectiveness and Shopping impacts and effectiveness and loyalty on the success of electronic marketing. Azad and Esmaeili (2012) performed a survey on measuring the effect of website on customer satisfaction. They investigated how a bank website can impact customer loyalty. The proposed study was applied for one of governmental Iranian banks called Bank of Industry and Mine. The study distributed a questionnaire among 330 people who use the internet banking of this bank and analyzed their feedback using structural equation system and all the hypothesis were confirmed.

Nezhad et al. (2011) investigated the impacts of customer value, customer satisfaction and customer loyalty on customer retention. The results indicated that all aspects of the customer value have positive relationships with customer satisfaction but only emotional value had a positive and direct relationship with customer loyalty. The study confirmed that while none of customer value aspects had direct and positive relationship with customer retention, both customer satisfaction and customer loyalty positively and directly affected customer retention.

Darvish et al. (2013) investigated the effect of six factors on electronic banking including easy access, design, transaction speed, security, information content and customer support on customer satisfaction. The proposed study was performed in different branches located in north east of city of Tehran, Iran named Tejarat. The study selected a sample of 200 customers, designed, and distributed a questionnaire among them. They reported that all six components significantly influenced on customer satisfaction. They also used a linear regression between the six independent variables and customer satisfaction and, using stepwise linear regression technique, the most suitable regression model was identified.

Hakkak and Zare (2013) investigated the relationship between marketing and customer's loyalty. The study designed a questionnaire consists of three parts where the first part was associated with customer information, the second part considered relationship marketing factors and the third part measured components of customer's loyalty. They reported that some components were not meaningful when the level of significance is five percent. Darvish et al. (2012) performed an empirical study on effective factors on entrepreneurial orientation in Iranian banking industry.

\section{The proposed study}

The proposed study of this paper considers the following eight hypotheses,

1. There is a significant relation between competition among providers and internet in insurance industry.

2. There is a significant relation between bargaining power of customers and internet in insurance industry.

3. There is a significant relation between bargaining power of suppliers, threat and internet in insurance industry.

4. There is a significant relation between starting a business and internet in insurance industry.

5. There is a significant relation between the threat of substitutes and internet in insurance industry.

6. There is a significant relation between customer satisfaction and internet in insurance industry.

7. There is a significant relation between perceived image and internet in insurance industry.

8. There is a significant relation between perceived quality and internet in insurance industry.

The questionnaire of this study consists of 48 multiple-choice questions. In addition, we gather participants' personal characteristics. The first eight questions of the survey are associated with the 
first hypothesis of this survey, which investigates whether implementation of internet has any influences on competitions among insurance providers or not. The next three questions, Questions 911, are associated with customers' bargaining attitudes and internet usage in insurance industry. In addition, questions 12-15, 16-20, 21-26, 27-34, 35-40 and 41-48 are associated with Bargaining power of suppliers, starting a business, the threat of substitutes, customer satisfaction, perceived image and perceived quality, respectively. Table 1 summarizes details of questions as well as the hypotheses.

\section{Table 1}

Research hypothesis and Questioner number

\begin{tabular}{lcccccccc}
\hline Question & $1-8$ & $9-11$ & $12-15$ & $16-20$ & $21-26$ & $27-34$ & $35-40$ & $41-48$ \\
\hline Hypothesis & 1 & 2 & 3 & 4 & 5 & 6 & 7 & 8 \\
\hline
\end{tabular}

All questions are designed in Likert scale from very little important to very important. Reliability and accuracy are from the scales and measurements of the scientific studies and are from the most important characteristics in an effective and accurate information gathering. Cronbach alphas have been calculated and they are summarized in Table 2 as follows,

\section{Table 2}

Questioner Alfa Cronbach

\begin{tabular}{llll}
\hline Variables & alpha & Variables & alpha \\
\hline Competition among providers & 0.784 & The threat of substitutes & 0.761 \\
Bargaining power of customers & 0.813 & Customer Satisfaction & 0.824 \\
Bargaining power of suppliers, threat of & 0.801 & Perceived image & 0.709 \\
Starting a business & 0.798 & Perceived quality & 0.792 \\
\hline
\end{tabular}

As we can observe from the results of Table 2, all Cronbach alpha are well above the minimum acceptable limit of 0.7. Primarily in all researches, there are some time, place and subject frames, which should be defined, carefully. Obviously all researchers encounter some obstacles and limitations such as time required for the study, research costs etc. The proposed study has been accomplished among insurance firms located in province of Gonbadekavoos in Iran, which were active during the year of 2013. The sample size is calculated as follows,

$n=\frac{N \times z_{\alpha / 2}^{2} \times p \times q}{\varepsilon^{2} \times(N-1)+z_{\alpha / 2}^{2} \times p \times q}$,

where $N$ is the population size, $p=1-q$ represents the yes/no categories, $z_{\alpha / 2}$ is CDF of normal distribution and finally $\varepsilon$ is the error term. Since we have $p=0.5, z_{\alpha / 2}=1.96$ and $N=10000$, the number of sample size is calculated as $n=96$. Generally, we can say that in analyzing data there is a quantitative dimension which is that special statistical calculation, and also there is a qualitative dimension which is analyzing, reasoning and concluding according to the results from statistical data. In order to analyze and conclude the obtained results and data in this study, except using statistical methodologies, question and interview with managers and agents, we have used Delphi method to define the accuracy of the dimensions and parameters of research variables the desired subject.

\section{The results}

This study investigates 8 hypotheses, which is defined by conceptual model of the study. In this study, the required information obtained from library resources, conceptual model of the study and attitudes from consultants and professors, and then in order to evaluate the data we have used a questionnaire in this study. Analyzing and evaluating the obtained information have been accomplished by questionnaires in two levels of descriptive analyze and perceptional analyze. The 
descriptive analyze includes descriptive analyzing and evaluating of demography including participants' personal information including gender, age, level of education, job, etc. and we evaluate special parameters of the study including amplitude, percent of amplitude, average and standard deviation. In our survey, $95 \%$ of the participants were male and only $5 \%$ of them were female. In terms of marital status, $61.3 \%$ of the participants were married and $38.7 \%$ of them were single. Fig. 1 demonstrates participants’ years of educational backgrounds.

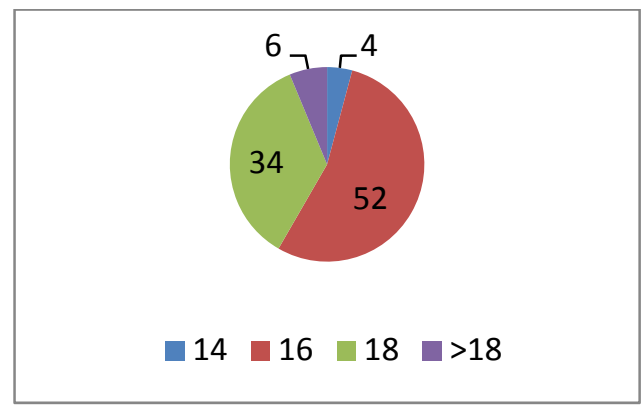

Fig. 1. Years of educational background

The proposed study uses the following to examine eight hypotheses

$\begin{cases}H_{0}: & \mu \leq 3 \\ H_{1}: & \mu>3\end{cases}$

We use t-student test to verify different hypotheses and Friedman test is implemented to rank them. Table 3 summarizes the results of t-student test.

\section{Table 3}

Statistical measures to test the hypotheses binomial

\begin{tabular}{|c|c|c|c|c|c|}
\hline Theories (Hypothesis) & Error & $\begin{array}{c}\text { Level of being } \\
\text { meaningful }\end{array}$ & $\begin{array}{c}\text { Test } \\
\text { Possibility }\end{array}$ & $\begin{array}{l}\text { Measured } \\
\text { Possibility }\end{array}$ & Result of the test \\
\hline $\begin{array}{l}\text { There is a significant relation between Competition among } \\
\text { providers and internet in insurance industry }\end{array}$ & 0.05 & 0.000 & 0.5 & 0.82 & $\mathrm{H}_{1}$ accepted \\
\hline $\begin{array}{l}\text { There is a significant relation between Bargaining power of } \\
\text { customers and internet in insurance industry }\end{array}$ & 0.05 & 0.000 & 0.5 & 0.73 & $\mathrm{H}_{1}$ accepted \\
\hline $\begin{array}{l}\text { There is a significant relation between Bargaining power of } \\
\text { suppliers, threat and internet in insurance industry }\end{array}$ & 0.05 & 0.000 & 0.5 & 0.87 & $\mathrm{H}_{1}$ accepted \\
\hline $\begin{array}{l}\text { There is a significant relation between Starting a business and } \\
\text { internet in insurance industry }\end{array}$ & 0.05 & 0.000 & 0.5 & 0.87 & $\mathrm{H}_{1}$ accepted \\
\hline $\begin{array}{l}\text { There is a significant relation between The threat of } \\
\text { substitutes and internet in insurance industry }\end{array}$ & 0.05 & 0.000 & 0.5 & 0.77 & $\mathrm{H}_{1}$ accepted \\
\hline $\begin{array}{l}\text { There is a significant relation between Customer Satisfaction } \\
\text { and internet in insurance industry }\end{array}$ & 0.05 & 0.000 & 0.5 & 0.82 & $\mathrm{H}_{1}$ accepted \\
\hline $\begin{array}{l}\text { There is a significant relation between Perceived image and } \\
\text { internet in insurance industry }\end{array}$ & 0.05 & 0.000 & 0.5 & 0.79 & $\mathrm{H}_{1}$ accepted \\
\hline $\begin{array}{l}\text { There is a significant relation between Perceived quality and } \\
\text { internet in insurance industry }\end{array}$ & 0.05 & 0.000 & 0.5 & 0.86 & $\mathrm{H}_{1}$ accepted \\
\hline
\end{tabular}

The results of Table 3 confirm that all null hypotheses can be rejected when the level of significance is five percent and we can accept all alternative hypotheses and conclude that internet plays essential role in terms of all eight different insurance perspectives. We have performed a non-binomial test and Table 4 demonstrates the results of our survey.

Based on the results of Table 4, all t-student values are statistically significance with P-value $=0.000$. This means that internet influences competition among providers, bargaining power of customers as well as suppliers, significantly. In addition, internet has meaningful impacts on starting a business, the threat of substitutes, customer satisfaction, perceived image as well as perceived quality. 
Table 4

Statistical measures to test the hypotheses

\begin{tabular}{|c|c|c|c|c|c|c|c|c|}
\hline \multirow[b]{2}{*}{ (Hypothesis) } & \multirow[b]{2}{*}{ Average } & \multicolumn{2}{|c|}{ 95\% Estimation } & \multirow[b]{2}{*}{$\begin{array}{c}\text { Test } \\
\text { Value }\end{array}$} & \multirow{2}{*}{$\begin{array}{l}\text { Level Of being } \\
\text { Meaningful }\end{array}$} & \multirow{2}{*}{$\begin{array}{c}\text { Measured } \\
\mathrm{t}\end{array}$} & \multirow{2}{*}{$\begin{array}{c}\text { Average } \\
\text { Standard Error }\end{array}$} & \multirow{2}{*}{$\begin{array}{l}\text { Standard } \\
\text { Deviation }\end{array}$} \\
\hline & & $\begin{array}{l}\text { Upper } \\
\text { Limit }\end{array}$ & $\begin{array}{c}\text { Lower } \\
\text { limit }\end{array}$ & & & & & \\
\hline $\begin{array}{l}\text { There is a significant relation between } \\
\text { competition among providers and } \\
\text { internet in insurance industry }\end{array}$ & 3.52 & 0.6144 & 0.4437 & 3 & 0.000 & 12.306 & 4.29 & 0.4146 \\
\hline $\begin{array}{l}\text { There is a significant relation between } \\
\text { bargaining power of customers and } \\
\text { internet in insurance industry }\end{array}$ & 3.52 & 0.6144 & 0.4437 & 3 & 0.000 & 12.306 & 4.29 & 0.4146 \\
\hline $\begin{array}{l}\text { There is a significant relation between } \\
\text { bargaining power of suppliers, threat and } \\
\text { internet in insurance industry }\end{array}$ & 3.3871 & 0.4669 & 0.3073 & 3 & 0.000 & 9.630 & 4.02 & 0.3876 \\
\hline $\begin{array}{l}\text { There is a significant relation between } \\
\text { starting a business and internet in } \\
\text { insurance industry }\end{array}$ & 3.4259 & 0.4579 & 0.3324 & 3 & 0.0000 & 11.508 & 3.365 & 0.4025 \\
\hline $\begin{array}{l}\text { There is a significant relation between } \\
\text { the threat of substitutes and internet in } \\
\text { insurance industry }\end{array}$ & 3.5984 & 0.4579 & 0.3324 & 3 & 0.0000 & 12.421 & 3.4587 & 0.3025 \\
\hline $\begin{array}{l}\text { There is a significant relation between } \\
\text { customer satisfaction and internet in } \\
\text { insurance industry }\end{array}$ & 3.6359 & 0.4579 & 0.3324 & 3 & 0.0000 & 10.521 & 3.12547 & 0.3789 \\
\hline $\begin{array}{l}\text { There is a significant relation between } \\
\text { perceived image and internet in } \\
\text { insurance industry }\end{array}$ & 3.3691 & 0.4579 & 0.3324 & 3 & 0.0000 & 10.369 & 3.41258 & 0.5258 \\
\hline $\begin{array}{l}\text { There is a significant relation between } \\
\text { perceived quality and internet in } \\
\text { insurance industry }\end{array}$ & 3.5624 & 0.4579 & 0.3324 & 3 & 0.000 & 10.369 & 3.6398 & 0.4718 \\
\hline
\end{tabular}

\section{Conclusion}

In this paper, we have presented an empirical investigation to study the effect of internet in insurance industry in Iran. The proposed study designed a questionnaire, distributed among some experts and analyzed them based on t-student test. The results of our survey have concluded that internet influences competition among providers, bargaining power of customers as well as suppliers, significantly. In addition, internet has meaningful impacts on starting a business, the threat of substitutes, customer satisfaction, perceived image as well as perceived quality. The results of this survey emphasizes on the relative importance of internet for building a better competitive insurance industry. Therefore, we need to consider some actions such as group meetings with employees and managers participating insurance company customers to better identify the needs and aspirations of both sides and solve problems and barriers.

We also need to have a better communication and interaction among multiple customers, employees and management through web sites and communications with stakeholders. In addition, we need to provide facilities and special rates for the use of electronic or cyber insurance by insurance and other central actors in these markets, such as insurance companies, brokers and insurance sales agents. Procurement agencies and branches of the company to pay damages to equipment and facilities for clients are among other necessary requirements of having better equipped units. Finally, participation in various programs sponsored by the insurance company's social, cultural and charitable are among other necessary actions needed.

\section{Acknowledgment}

The authors would like to thank the anonymous referees for constructive comments on earlier version of this paper.

\section{References}

Assael, H. (1987). Consumer behavior and marketing action (Vol. 3). Boston; Kent Publishing Company. 
Azad, N \& Esmaeili, A. (2012). A survey on measuring the effect of website on customer satisfaction. Management Science Letters, 2(5), 1639-1644.

Caruana, A., Money, A. H., \& Berthon, P. R. (2000). Service quality and satisfaction-the moderating role of value. European Journal of Marketing,34(11/12), 1338-1353.

Cassiman, B., \& Sieber, S. (2002). The impact of the internet on market structure. Handbook of Information Technology in Organizations And Electronic Markets.

Darvish, H., Alvani, S.M., salehi sadagiani, J., \& Abbaszadeh, H. (2012). An empirical study on effective factors on entrepreneurial orientation in Iranian banking industry. Management Science Letters, 2(7), 2591-2600.

Darvish, H., Moayeri, M., Faradonbe, M \& Naderifar, A. (2013). A survey on relationship between customer satisfaction and electronic banking features: A case study of Tejarat bank in Iran. Management Science Letters, 3(2), 425-430.

Feizollahi, S., Shirmohammadi, A \& Hassani, R. (2013). Developing a conceptual model for selecting and evaluating online markets. Management Science Letters, 3(4), 1203-1208.

Hakkak, M \& Zare, N. (2013). Evaluating the impact of relationship marketing components on customers' loyalty level: Evidence from Iran Khodro Corporation. Management Science Letters, 3(2), 519-526.

Kim, W. C., \& Mauborgne, R. (1998). Value innovation: the strategic logic of high growth. IEEE Engineering Management Review, 26(2), 8-17.

Nezhad, S., Jomehri, N \& Javanshir, H. (2011). An empirical study to determine the critical success factors on customer retention: A case study of Iranian banking sector. Management Science Letters, 1(2), 223-234.

Porter, P. (2001). Strategy and Internet. Harward Business Review.

Sehhat, S. (2012). An empirical survey to measure the impact of different factors on the success of electronic marketing. Management Science Letters, 2(6), 2187-2192. 